\section{Close contact and AIDS}

SIR - Max Perutz ${ }^{1}$ discusses the question you raised of what a public official (or anyone for that matter) should do when he knows that official policy poses potential dangers. This problem arose in the case of Professor Jean-Pierre Allain, jailed last year in France for failing to prevent the distribution of HIV-contaminated bloodclotting factors to haemophiliacs. Perutz mentioned that Allain, alarmed by the use of HIV-contaminated blood, attempted to voice his fears to the public by giving an interview to the French newspaper Le Matin, but the interview was not published. This made me wonder what lesson might be drawn from the difficulties I had in publishing critical remarks about statements released in 1986 by the US Surgeon General and by the Institute of Medicine of the National Academy of Sciences concerning the risks of HIV transmission.

The surgeon general ${ }^{2}$ said about family members living with HIV-infected individuals that: "There is no evidence of transmission (spread) of AIDS virus by everyday contact even though these family members shared food, towels, cups, razors, even toothbrushes, and kissed each other." The report of the Institute of Medicine ${ }^{3}$ similarly stated that "there is now substantial evidence against transmission through so-called casual contact, including regular close contact (such as that occurring in sharing accommodations, eating utensils, or even toothbrushes) ....".

Both statements were based primarily on one scientific paper, by Friedland $e t$ $a l .^{4}$. That paper was accompanied by a guest editorial ${ }^{5}$, which concluded: "The evidence presented by Friedland $e t a l$. is a powerful argument to counter the public's fear of casual contagion ....". Unfortunately, careful reading of the Friedland paper revealed that their study was quite limited, and this was soon pointed out ${ }^{6}$; the study could not rule out a risk as high as one chance in about 35 . Yet such a crude study appeared to provide the stated foundation for government policy.

My contribution was to do a survey among scientists to find the largest risk of household transmission of HIV that they associated with the comforting words "extremely and reassuringly low" subsequently used by Friedland et al. ${ }^{7}$; in brief, the survey indicated a risk of roughly 1 in 100,000 . My aim was to point out the great disparity between what officials claimed was proven and what was actually proven, but neither Nature (in 1987) nor Science (in 1989) would publish it. The Lancet, to its credit, published the essential elements of my letter virtually upon receipt ${ }^{8}$.

I do not know what current studies show about the risk of HIV transmission by household contact. I do know, however, that in 1986 there was a vigorously stated claim that the risk was negligible, but the evidence cited to support the claim was woefully inadequate - by a factor of about 3,000. Although a deficient scientific evaluation was uncritically accepted by a large section of the scientific community and was cited widely and approvingly in public forums, the two leading general science journals declined to air the matter. I think there may be a parallel with the failure of Le Matin to publish the interview with Allain.

\section{Inwin Tessman}

Department of Biological Sciences,

Purdue University,

West Lafayette, Indiana 47907, USA

1. Perutz, M Nature 367, 504 (1994)

2. Surgeon General's Report on Acquired Immune Deficiency Syndrome. p. 13 (Washington, DC, 1986)

3. Confronting Aids p. 50 (Institute of Medicine, National Academy of Sciences, Washington, DC, 1986).

4. Friedland, G. H. et al. New Engl. J. Med. 314, 344-349

(1986).
5. Sande, M. A. New Engl. J. Med. 314, 380-382 (1986)

5. Sande, M. A. New Engl. J. Med. 314, 380-382(1986).
6. McDonald, C. J. \& Rogers, M. P. New Engl. J. Med. 315. 258 (1986)

7. Friedland, G. etal. NewEngl. J. Med. 315. 258-259 (1986)

8. Tessman, I. Lancet II, 982 (1989)

\section{Ponzi economics}

SIR - Nature confirms (368, 177; 1994) what many working academic scientists have long suspected; namely that during recent years, US universities mortgaged the indirect-cost components of future grants to build new facilities on the speculation that these facilities would attract sufficient new grant funding to pay for the building spree. Outside the groves of academe, pyramid schemes of this kind are generally named after the celebrated swindler Charles Ponzi, whose operation collapsed in the early 1920 s.

The panic among the administrators of the American Association of Universities is due to the approaching collapse, belatedly visible to them, of their own Ponzi operations. It is no surprise that they wish the cost of the collapse to be shifted to the research enterprise as a whole, and away from the indirect-cost charges they have been using for leverage. This simply reveals their true inclinations, as does their view that university success is measured not by the quality of the research or the character of the education, but rather by the ability to "expand aggressively" (as Dennis Dougherty of the University of Southern California so nicely puts it) by means of Ponzi economics.

Although pyramid schemes are not unheard of in normal commerce, they are subject to prosecution when false representations are made. One wonders what representations university officials made to the National Institutes of Health and the National Science Foundation in order to justify their indirect-cost charges. Did they reveal that these funds were used to leverage financing for new facilities in the hope of adding still more grants (with still more indirect-cost return) to the pyramid? An investigation of this subject might result in some of the most inventive university officials joining counterparts in the investment business, such as Charles Keating and Michael Milken, in a period of residence at another kind of federal institution.

This outcome might wonderfully concentrate the minds of academic vicepresidents on those functions that distinguish a university from an acquisition holding company. Moreover, an improvement in the climate of integrity in the academic world would improve the environment for honest research and serious education, two functions that may still have a place at research universities.

\section{Jonathon Gallant}

Department of Genetics,

University of Seattle,

Seattle, Washington 98195, USA

\section{Slovak science}

SIR - Alison Abbott's pessimistic article, "Slovak science lacks finance, direction ..." (Nature 366, 386; 1994) is still too optimistic.

The total budget of the Slovak Academy of Sciences, which was between SK800 and SK 900 million a year in the late 1980s, has fallen to SK381 million this year. And inflation during this five-year period is close to a factor of three, so that the budget has decreased in real terms by a factor of more than five.

But conditions for doing science worsened considerably in the late 1980s. Salaries were then close to a half of the science budget, but they are now a much higher proportion. This has not resulted in an improvement in the standard of living of research scientists. Some junior scientists with PhDs who are married with children are earning less than what is recognized as a living wage. After subtracting salaries from the science budget, the shrinkage of the remainder is much more evident. Energy and mailing costs are rising more quickly than inflation, so the money available for library facilities, instruments, equipment, travel and so on has decreased considerably.

The quality and amount of science in Slovakia has not fallen, but the continued existence of basic research is in question. Nevertheless, the quality and amount of science has not fallen - at least at this institute.

\section{E. Bēták}

Institute of Physics,

SlovakAcademy of Sciences,

84228 Bratislava, Slovakia 